\section{Genealogy of Contemporary North American Lettuce}

\author{
Mark A. Mikel \\ Roy J. Carver Biotechnology Center and Department of Crop Sciences, \\ University of Illinois, 2608 Institute for Genomic Biology, 1206 West \\ Gregory Drive, Urbana, IL 61801 and Maize Lineage LLC, 3408 Mill \\ Creek Court, Champaign, IL 61822
}

Additional index words. Lactuca sativa, plant breeding, genetics, germplasm

\begin{abstract}
To determine the genealogy of cultivated lettuce in the United States, a survey was conducted on the pedigree of proprietary and publicly developed lettuce cultivars registered from 1970 through 2004 . This was facilitated through information furnished by the U.S. Plant Variety Protection Act, U.S. patent, and journal publication of registered cultivars. In total, there were 328 registered cultivars of which $\mathbf{9 0 . 5 \%}(297$ cultivars) were from proprietary and $9.5 \%$ (31) from public breeding programs. The lettuce cultivars of this era are $61.6 \%$ crisphead, $19.5 \%$ loose leaf, $13.7 \%$ cos/romaine, 4.9\% butterhead, and $0.3 \%$ latin lettuce types. To facilitate an understanding of current U.S. lettuce germplasm, the most recombined and putatively elite cultivars in the development of new cultivars were identified. The 10 most recombined cultivars were 'Salinas' (parent of 28 new cultivars), 'Calmar' (27), 'Vanguard' (22), 'Vanguard 75' (13), 'Vanmax' (13), 'Prize Head' (12), 'Parris Island Cos' (12), 'Empire' (11), 'Great Lakes 659' (11), and 'Red Coach 74' (10). The types of breeding populations used for new cultivar development during this era were two-parent $(52 \%$ of new cultivars), within cultivar selection (31\%), three-parent $(7 \%)$, backcross two or greater $(5 \%)$, backcross one $(2 \%)$, four or more parents $(2 \%)$, and interspecific cross $(1 \%)$.
\end{abstract}

Lettuce (Lactuca sativa) is the most commonly consumed of fruits or vegetables in the United States as determined by a mid-1990s survey (Hu et al., 2005; Johnston et al., 2000). Lettuce is a contributor of dietary vitamins $\mathrm{A}$ and $\mathrm{C}$ as well as lesser amounts fiber, iron, and calcium (Thompson, 1951; USDA, 2005). Lettuce grown in the United States is crisphead, cos/romaine, loose leaf (leaf), and butterhead types (Cook, 2002; Ryder, 1986a; Whitaker, 1974). The USDA National Agricultural Statistics Service estimates that crisphead $(74,907$ ha), romaine $(34,196 \mathrm{ha})$, and leaf lettuce (25,778 ha) accounted for the 134,881 ha of U.S. commercial lettuce production in 2005 (Anonymous, 2006). Proportionately, crisphead lettuce was $56 \%$, romaine $25 \%$, and leaf lettuce $10 \%$ of U.S. lettuce production area. A 5-year trend (2000 through 2005) shows romaine lettuce production hectarage increasing $66 \%$ and leaf lettuce increasing by $26 \%$, whereas crisphead

\footnotetext{
Received for publication 6 Dec. 2006. Accepted for publication 8 Feb. 2007.

I thank Richard Johnson, John W. Dudley, and the anonymous peer reviewers for their thoughtful critique of this manuscript. I am grateful to the Roy J. Carver Biotechnology Center of the University of Illinois at Urbana-Champaign for financing the publication of this research. Appreciation is extended to Robin Davis of the Plant Variety Protection Office for assistance with purchasing access to public domain PVPA certificates. It is time to establish real-time access to all PVPA certificates through web-based download; this is a rich database for agricultural research.

E-mailmmikel@uiuc.edu
}

lettuce production has remained relatively constant. For example, U.S. lettuce production was $90 \%$ crisphead in $1986,80 \%$ in 1994, and 56\% in 2005 (Anonymous, 2006; Ryder, 1986a; Waycott and Ryder, 1994). Contributing to the increasing use of romaine lettuce is the popularity of the Caesar salad (Dunne, 2005; Ryder, 1986a). Home gardeners in the United States commonly grow leaf, butterhead, and romaine lettuce but have less success with the environmentally sensitive crisphead varieties. Worldwide, other types of lettuce are also popular, including latin and stem lettuce (Ryder, 1986a; Thompson, 1951).

Public and private breeding programs have worked diligently to improve lettuce through recombination and selection focusing on cultivar improvement for yield, environmental adaptability, quality, disease and insect resistance. Improvement of lettuce has largely been accomplished from recombination of cultivars within $L$. sativa but on occasion from recombination with related noncultivated wild Lactuca species such as L. serriola, L. saligna, and L. virosa (Lebeda et al., 2004; Whitaker and Provvidenti, 1983). The proprietary breeding efforts in lettuce cultivar development are increasing. Legal protection of proprietary cultivars is accomplished by registration either through the Plant Variety Protection Act (PVPA) enacted in 1970 or through utility patents of seed-propagated plants from the U.S. Patent and Trademark Office after 1985 (Janis and Kesan, 2001). Both PVPA and patent offer protection that prevents direct commercial use of a registered cultivar without permisand of precut bagged salads in grocery stores sion of the originator (Mikel, 2006). Whereas U.S. patents prevent the use of registered material for breeding without assignee permission, PVPA registration does allow the use of protected material for breeding. Because PVPA and patent registration documentation is in the public domain, pedigrees and characteristics of these proprietary lettuce cultivars are publicly available.

The objective of this study was to understand contemporary North American lettuce germplasm by surveying public and proprietary cultivars of 1970 to 2004 by: 1) identifying the most elite progenitor cultivars by tabulating the cumulative number of times each cultivar has been used as a parent in breeding a new registered cultivar; 2) tracing the lineage and origin of these elite cultivars; and 3) summarizing the breeding methodology used in the development of the registered varieties of this era.

\section{Materials and Methods}

For the era of this study (1970 to 2004), the most important progenitor cultivars were determined for the 328 registered lettuce cultivars surveyed. This was accomplished by tabulating the cumulative number of times each parental cultivar was used in the development of a newly registered cultivar. U.S. PVPA, U.S. Patent, or publication in HortScience provided the pedigrees of the lines. Lettuce breeders are extremely knowledgeable regarding the performance of lettuce cultivars and devote much of their breeding effort into recombining those cultivars they determine to be most elite. Thus, elite progenitor or founder lettuce cultivars were identified as those lines that breeders have recombined the most frequently in the development of new registered commercial cultivars. In addition, lettuce type (crisphead, romaine/cos, leaf, or butterhead), year of release, and originator were determined for each progenitor line.

The categories of breeding populations from which the 328 lettuce varieties of this era were developed consisted of: A) within cultivar selection; B) two-parent "cultivar A $\times$ cultivar B"; C) three-parent " $(\mathrm{A} \times \mathrm{B}) \times \mathrm{C}$ "; D) four or more parents; $E$ ) backcross one " $(\mathrm{A} \times \mathrm{B}) \times \mathrm{B}$ "; F) backcross two or greater; and G) cross involving other Lactuca species (L. serriola, L. virosa, L. saligna). The category of breeding population was determined for each of the registered lettuce cultivars. Breeding population formulation consists of cumulative recombination before the onset of selfing.

An overall summary of the relationship of the previously identified elite lettuce cultivars is shown graphically through tracing the lineage of each cultivar for as many generations as possible (Fig. 1). The progenitor cultivars identified earlier by recombination frequency are shown as shaded boxes. Complex crosses used in the development of new cultivars are simplified as much as possible. Furthermore, uses of strain and plant numbers during inbreeding were omitted unless 


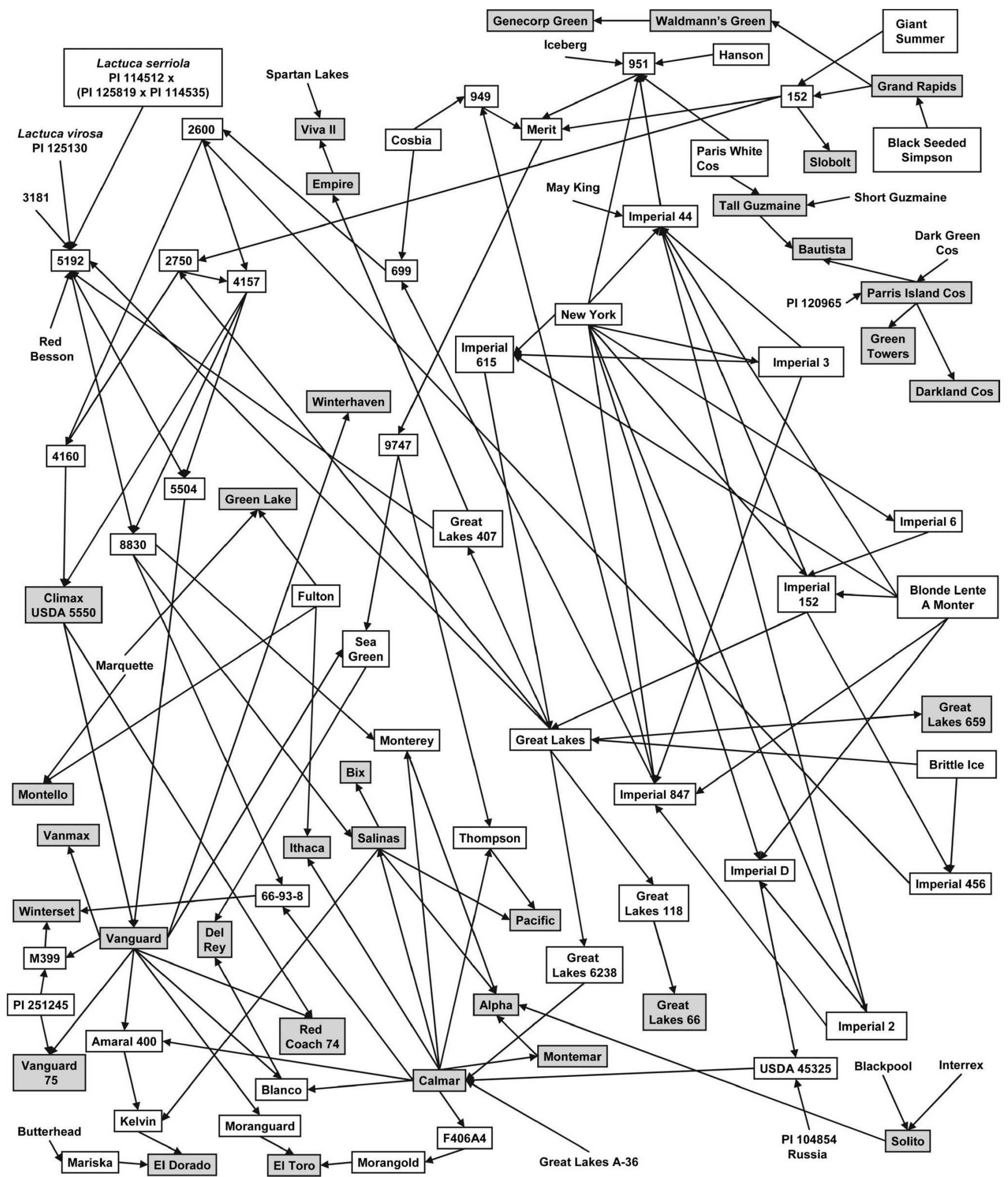

Fig. 1. This figure illustrates the lineage of each lettuce cultivar by descent as depicted by arrows originating from parent and pointing to their progeny. Derivations are furnished in Table 2 for those varieties depicted in shaded boxes. Breeding lines '152', '699', '949', '951', '2600', '2750', '4157', '4160', '5504', and '5192' and cultivar 'Merit' have their pedigree derivation shown in Thompson and Ryder (1961). Derivation of 'Imperial D', 'Imperial 2', 'Imperial 3', 'Imperial 6', 'Imperial 44', 'Imperial 152', 'Imperial 615', and 'Imperial 847' are described by Jagger et al. (1941). References are as shown for the pedigree derivation of 'Winterset', 'M399', and '66-93-8' (Ryder, 1986b); 'Salinas' and '8830' (Ryder, 1979a); 'Vanguard 75' (Ryder 1979b); 'Great Lakes' and 'Imperial 456' (Bohn and Whitaker, 1951); 'Pacific', 'Thompson', and '9747' (Ryder and Robinson, 1991); 'Sea Green' (Ryder, 1981); 'USDA 45325' (Compositdb, 2006); 'Great Lakes 407' (Anonymous, 1956); 'Great Lakes 118' (Anonymous, 1958); 'Great Lakes 6238' (Anonymous, 1965); and 'Monterey' (Lower, 1973). Pedigree derivation are from Plant Variety Protection Act (PVPA) certificates for 'Morangold' (PVPA 7600039), 'F406A4' (PVPA 7600039 and PVPA 7400014), 'Blanco' (PVPA 7800062), 'Kelvin' (PVPA 8700182), 'Amaral 400' (PVPA 7800083), and 'Mariska' (PVPA 9300014). 
information is gained from their use. Cultivar names are used rather than experimental and breeding line designations whenever possible. For example, if a breeding line is used that is later renamed with a cultivar name designation, then its cultivar name was used for clarity.

\section{Results and Discussion}

The pedigrees of a total of 328 surveyed lettuce cultivars were registered and made public from 1970 through 2004 through U.S. PVPA, U.S. Patent, or publication in HortScience. There is frequently a hiatus of 2 to 3 years from the date of application for PVPA or patent registration until completion of review. During this time, the application is not publicly available. Overall, $90.5 \%$ and $9.5 \%$ of lettuce cultivars of this era were from proprietary and public programs, respectively (Table 1). Two thirds of the cultivars were developed or acquired by the following: Seminis Vegetable Seeds 32\% (106 cultivars), Harris Moran 10\% (33), Progeny Advanced Genetic 6\% (21), Paragon Seed $6 \%$ (20), U.S. Department of Agriculture (USDA) 5\% (17), Enza Zaden Beheer B.V. 4\% (13), and Rijk Zwaan 4\% (13). Format of lettuce cultivar registration is through U.S. PVPA (294 cultivars), HortScience (30), and U.S. patent (9). All cultivars from proprietary programs were registered through U.S. Patent or PVPA. Five proprietary cultivars were double-protected by both U.S. Patent and U.S. PVPA. Publicly developed cultivars, either academic or USDA, were described in their publication of release in HortScience but were not registered by PVPA or patent. During the first half of this era (1970 to 1986), proportionately more cultivars were registered by public programs than during the second half (1987 to 2004), $18 \%$ versus $6 \%$, respectively. Nonetheless, despite their small numbers, the publicly developed lines played a pivotal role in the development of today's germplasm base. Apparently, commercial growers tended to rely on publicly developed lettuce cultivars as opposed to varieties developed independently by the private sector both for production and breeding of new cultivars (Dunne, 2005). For example, in the United States, the most produced lettuce of the 1960 s and 1970 s were the crisphead varieties 'Calmar' and 'Vanguard' that were developed at the University of California

Table 1. Type and origin of registered U.S. lettuce cultivars.

\begin{tabular}{|c|c|c|c|c|c|c|}
\hline \multirow[b]{2}{*}{ Lettuce type } & \multicolumn{2}{|c|}{1970 to 1986} & \multicolumn{2}{|c|}{1987 to 2004} & \multicolumn{2}{|c|}{ Overall } \\
\hline & Number & Percent & Number & Percent & Number & Percent \\
\hline Crisphead & 72 & 80 & 130 & 55 & 202 & 61.6 \\
\hline Loose Leaf & 12 & 13 & 52 & 22 & 64 & 19.5 \\
\hline Cos/Romaine & 3 & 3 & 42 & 18 & 45 & 13.7 \\
\hline Butterhead & 3 & 3 & 13 & 5 & 16 & 4.9 \\
\hline Latin & 0 & 0 & 1 & 0 & 1 & 0.3 \\
\hline Total & 90 & & 238 & & 328 & \\
\hline \multicolumn{7}{|l|}{ Developed by } \\
\hline Proprietary program & 74 & 82 & 223 & 94 & 297 & 90.5 \\
\hline Public program & 16 & 18 & 15 & 6 & 31 & 9.5 \\
\hline Total & 90 & & 238 & & 328 & \\
\hline
\end{tabular}

and USDA, respectively (Ryder, 1991). These two varieties were later replaced with the USDA developed cultivar 'Salinas', which quickly became the most produced lettuce cultivar of the 1980s (Ryder, 1979a). This validates the criterion described herein in which 'Salinas', 'Calmar', and 'Vanguard' were also determined to be elite progenitor cultivars (Table 2). Of the progenitor cultivars in Table 2, breeders at public institutions developed 13 and proprietary research programs developed 18 cultivars. Ten of these progenitors of today's lettuce germplasm were developed before 1960 .

Nearly two thirds of new cultivars from this era were crisphead $(61.6 \%)$ followed by leaf $(19.5 \%)$, romaine $(13.7 \%)$, butterhead $(4.9 \%)$, and latin $(0.3 \%)$ lettuce types. Concomitant with increasing use of leaf and romaine lettuce was an increase in the development of these types. The proportion of new leaf lettuce cultivars increased from $13 \%$ to $22 \%$, and romaine types increased from $3 \%$ to $18 \%$ of new cultivars between the first half (1970 to 1986) and the second half (1987 to 2004) of this era, respectively (Table 1).

A generalization of the development of today's crisphead lettuce varieties features essentially three cycles of recombination: 'New York' type (Cycle 0), 'Imperial' type (C1), and 'Great Lakes' type (C2), leading to the crisphead varieties of today (C3). The development of the 'Imperial' type (C1) was primarily through recombination of ' $\mathrm{New}$ York' with 'Blonde Lente A Monter' or from selection within 'New York' for improved disease resistance. The 'Imperial' cultivars exhibited greatly improved resistance to the disease brown blight and were better adapted to the southwestern United States (Whitaker, 1974). The second cycle resulted in 'Great Lakes' type varieties primarily from recombination of 'Imperial' type cultivars with 'Brittle Ice'. 'Great Lakes' cultivars were stress-tolerant, resistant to the physiological disorder of tipburn, and widely adapted (Whitaker, 1974). Within cultivar selection was common within 'Great Lakes', which optimized the environmental adaptation of 'Great Lakes' and created many commercial varieties such as 'Great Lakes A-36', 'Great Lakes 66', 'Great Lakes 118', 'Great Lakes 407', 'Great Lakes 428', 'Great Lakes 6238', and 'Pacific Lakes'.

'Salinas', 'Calmar', 'Vanguard', 'Vanguard 75', and 'Vanmax' are the most prev-

HortScience Vol. 42(3) June 2007 alent progenitors in the background of today's crisphead lettuce varieties (Table 2). The latter three are close 'Vanguard' types derived through either selection within 'Vanguard' ('Vanmax') or backcross isoline conversion of 'Vanguard' ('Vanguard 75'). The varieties 'Salinas', 'Vanguard', 'Vanguard 75', and 'Vanmax' have the common progenitor PI 125130 (L. virosa). The original objective for the introgression of $L$. virosa into crisphead lettuce (L. sativa) was to breed for robust root system and decreased leaf drop. The genealogy of current crisphead cultivars can be split into two groups. The first group is comprised of cultivars developed from $L$. virosa through the breeding line '5192' (PI 125130, L. virosa derived) from either direct progeny of ' 5192 ', through the breeding line ' 8830 ' (lineage of cultivars 'Salinas', 'Winterset', and 'Monterey'), or by way of the breeding line '5504' (lineage of cultivars 'Vanguard', 'Vanguard 75', 'Vanmax', and 'Red Coach 74'). The second group is not $L$. virosa derived and consists of 'Calmar' and its progeny 'Ithaca' and 'Montemar'. 'Calmar' is a remarkable cultivar of 'Great Lakes' group, which remained the industry standard for 15 years since its release in 1960. 'Salinas' resulted from recombination between these two groups. Also not L. virosa derived are 'Montello', 'Green Lake', 'Empire', and 'Viva II' (Fig. 1). 'Montello' and 'Green Lake' are recombinant lines developed from the cultivar 'Fulton'. Cultivars 'Empire' and 'Viva II' are in the 'Great Lakes 407' derived lineage.

Other interspecies crosses with $L$. sativa for new cultivar development include crosses with $L$. saligna and $L$. serriola. The cultivar 'Salad Bibb' was developed through a series of crosses with L. saligna with several L. sativa cultivars (PVPA 8500060). The cultivars 'Calrey' and 'Calrico' were derived from crossing $L$. sativa cultivars with L. serriola (PI 91532), a source of downy mildew resistance (Wehner, 1999).

Lettuce breeders have increased genetic diversity and achieved disease resistance through breeding cultivated lettuce with noncultivated or wild lettuce types. Recombination of 'Great Lakes' varieties with PI 104854, a downy mildew-resistant Russian wild-type lettuce, resulted in the development of 'Calmar'. Wild Egyptian lettuce (PI 251245) was used to introduce lettuce mosaic virus (LMV) resistance in 'Vanguard' by backcross breeding resulting in 'Vanguard $75^{\prime}$ and later through recombination additional lettuce mosaic-resistant varieties. Breeding of cultivated lettuce with other Lactuca species and wild-type lettuce germplasm has significantly contributed to the genetic makeup of today's lettuce varieties.

Leaf type lettuce cultivars were recombined primarily with each other. The most recombined leaf type lettuce is 'Prize Head' followed by 'Waldmann's Green' (Table 2). The loose leaf lettuce 'Grand Rapids' has contributed to the development of today's crisphead cultivars through the presence of a small proportion of 'Grand Rapids' in the 


\begin{tabular}{|c|c|c|c|c|c|c|}
\hline Cultivar & Pedigree derivation $^{z}$ & Type & $\begin{array}{l}\text { Year of } \\
\text { release }\end{array}$ & Citation & Originator $^{y}$ & $\begin{array}{l}\text { Recombinant } \\
\text { frequency }^{\mathrm{x}}\end{array}$ \\
\hline Calmar & $\begin{array}{l}\text { 'Great Lakes A-36' } \times \\
\text { ('Great Lakes 6238' } \times \\
\text { USDA '45325') }\end{array}$ & Crisphead & 1960 & Anonymous, 1965 & Univ. of Calif. & 27 \\
\hline Vanguard & '5550’ X'5504' & Crisphead & 1958 & Thompson and Ryder, 1961 & USDA & 22 \\
\hline Vanguard 75 & 'Vanguard' BC6 × PI 251245 & Crisphead & 1975 & Ryder, 1979b & USDA & 13 \\
\hline Vanmax & 'Vanguard' Selection & Crisphead & 1971 & PVPA 7100096 & Harris Moran & 13 \\
\hline Empire & $\begin{array}{l}\text { Complex Hybrid } \times \\
\text { 'Great Lakes } 407 \text { ' }\end{array}$ & Crisphead & 1957 & Anonymous, 1960 & USDA & 11 \\
\hline Great Lakes 659 & 'Great Lakes' selection & Crisphead & 1944 & Compositdb, 2006 & Dessert Seed Co. & 11 \\
\hline Red Coach 74 & 'Climax' $\times$ 'Vanguard' & Crisphead & 1974 & PVPA 7400010 & $\begin{array}{l}\text { Koninklijke } \\
\text { Zaaizaadbedrijven }\end{array}$ & 10 \\
\hline Waldmann's Green & 'Grand Rapids' Selection & Loose leaf & 1958 & Compositdb, 2006 & John Waldmann & 8 \\
\hline Darkland Cos & $\begin{array}{l}\text { 'Parris Island } \\
\text { Cos' selection }\end{array}$ & $\operatorname{Cos}$ & 1990 & PVPA 9000137 & $\begin{array}{l}\text { Central Valley } \\
\text { Seeds }\end{array}$ & 8 \\
\hline Montello & 'Marquette' × 'Fulton' & Crisphead & 1978 & Compositdb, 2006 & Univ. of Wis. & 6 \\
\hline Bautista & $\begin{array}{l}\text { 'Parris Island Cos' } \times \\
\text { 'Tall Guzmaine' }\end{array}$ & $\operatorname{Cos}$ & 1991 & PVPA 9100259 & Royal Sluis & 5 \\
\hline El Dorado & 'Kelvin' BC4 × 'Mariska' & Crisphead & 1993 & PVPA 9300014 & Royal Sluis & 5 \\
\hline Great Lakes 66 & 'Great Lakes 118' selection & Crisphead & 1953 & $\begin{array}{l}\text { Compositdb, 2006; } \\
\quad \text { Anonymous, } 1958\end{array}$ & $\begin{array}{l}\text { Associated Seed } \\
\text { Growers }\end{array}$ & 5 \\
\hline Pacific & 'Thompson' $\times$ 'Salinas' & Crisphead & 1986 & Ryder and Robinson, 1991 & USDA & 5 \\
\hline Slobolt & '152' Selection & Loose leaf & 1944 & Thompson and Ryder, 1961 & USDA & 5 \\
\hline Winterhaven & 'Vanguard' Selection & Crisphead & 1974 & PVPA 7400015 & Harnish-Brinker Seed & 5 \\
\hline Green Towers & 'Parris Island Cos' selection & $\operatorname{Cos}$ & 1986 & PVPA 8600135 & Harris Moran & 5 \\
\hline Alpha & $\begin{array}{l}{[(\text { 'Montemar' } \times \text { 'Monterey') } \times} \\
\text { 'Solito'] } \times \text { 'Salinas' BC1 }\end{array}$ & Crisphead & 1990 & PVPA 9000055 & Harris Moran & 4 \\
\hline Bix & 'Salinas' Selection & Crisphead & 1986 & PVPA 8600110 & $\begin{array}{l}\text { Seminis Vegetable } \\
\text { Seeds }\end{array}$ & 4 \\
\hline Solito & 'Blackpool’ × 'Interrex’ & Butterhead & $1970 \mathrm{~s}$ & $\begin{array}{l}\text { Center for Genetic } \\
\text { Resources, } 2006\end{array}$ & & 4 \\
\hline Viva II & 'Empire' × 'Spartan Lakes' & Crisphead & 1980 & PVPA 8000043 & $\begin{array}{l}\text { Koninklijke } \\
\text { Zaaizaadbedrijven }\end{array}$ & 4 \\
\hline Winterset & ‘66-93-8’ × ‘M399’ & Crisphead & 1984 & Ryder, 1986b & USDA & 4 \\
\hline
\end{tabular}

${ }^{\mathrm{z}} \mathrm{Abbreviations} \mathrm{are} \mathrm{as} \mathrm{follows:} \mathrm{plant} \mathrm{introduction} \mathrm{(PI)} \mathrm{and} \mathrm{backcross} \mathrm{(BC)} \mathrm{such} \mathrm{that} \mathrm{BC} 1$ is backcross 1 and so forth.

${ }^{y}$ Originators are U.S. Dept. of Agriculture (USDA), University of California (Univ. of Calif.), Harris Moran, S.C. Agriculture Experiment Station (AES), Dessert Seed Company, Koninklijke Zaaizaadbedrijven, John Waldmann, Central Valley Seeds, New York Agriculture Experiment Station (AES), University of Wisconsin (Univ. of Wis.), Royal Sluis, Associated Seed Growers, Harnish-Brinker Seed, Seminis Vegetable Seeds, and Eugene Davis.

${ }^{x}$ Recombination frequency is the cumulative number of times a cultivar is used in the development of a registered cultivar of this era.

PVPA = Plant Variety Protection Act.

pedigree of many crisphead varieties (Fig. 1). Development of new romaine lettuce varieties was accomplished mainly by recombination of cultivars within the type. The key component of today's romaine germplasm is the highly recombined 'Parris Island Cos'. For butterhead lettuce types, 'Solito' is the most recombined. Butterhead lettuce has limited use in the United States as a result of its poor shipping quality, but does have a presence in seasonal local markets.

Of the 328 registered lettuce varieties from 1970 to the present, half were derived directly from two-parent, $7 \%$ were derived from three-parent, and $2 \%$ from populations with more than three parents (Table 3). Backcross breeding was used in the derivation of $\approx 7 \%$ of lettuce cultivars, most predominantly backcross four or greater isoline conversions of existing cultivars for specific insect or disease resistance. Interestingly, nearly one third of new varieties were derived from selection within existing lettuce varieties. Thompson and Ryder (1961) noted that the cultivar 'Vanguard' was released as an F4 line whose unfixed genetic variation enabled seedsmen to select and fix through inbreeding better-adapted cultivars. To exploit this residual variation, breeders and seedsmen partnered in selection within existing cultivars.
Of the three most recombined lettuce cultivars 'Calmar', 'Salinas', and 'Vanguard', each had five, four, and three new cultivars developed directly from within cultivar selection, respectively. In contrast, for dent corn breeding populations during the same era, Mikel and Dudley (2006) reported that the use of two-parent populations predominated in the development of $75 \%$ of new corn lines. No registered corn inbreds were developed from selection within inbred lines.

Lettuce breeding involves simultaneous improvement of numerous characters. Efforts in the United States have predominantly been in the development of crisphead varieties, but 
Table 3. Breeding methodology for lettuce cultivar development.

\begin{tabular}{lcc}
\hline Breeding method $^{\mathrm{z}}$ & Number $^{\mathrm{y}}$ & Percent $^{-}$ \\
\hline Two-parent & 171 & 52 \\
Selection within cultivar & 101 & 31 \\
Three-parent & 24 & 7 \\
Backcross 2 or more & 15 & 5 \\
Multiparent (greater than & & \\
$\quad$ three-parent) & 8 & 2 \\
Backcross 1 & 5 & 2 \\
Cross involving other & & \\
$\quad$ Lactuca species & 4 & 1 \\
Total & 328 &
\end{tabular}
328

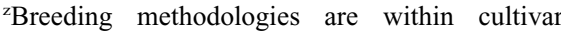
selection; two-parent "cultivar A $\times$ cultivar B"; selection within cultivar; three-parent " $(\mathrm{A} \times \mathrm{B}) \times$ C"; backcross 2 or greater; multiparent with four or more parents; backcross 1 " $(\mathrm{A} \times \mathrm{B}) \times \mathrm{B}$ ”; and cross involving other Lactuca species (L. serriola, L. virosa, L. saligna).

y Number of registered cultivars from 1970 through 2004.

increased consumer demand for romaine and leaf lettuce is shifting the focus to improvement of these types, primarily for shipping quality and environmental adaptability. Lettuce breeders have access to a tremendous amount of diversity for cultivar improvement. The Center for Genetic Resources (2006) lists 1390 accessions of lettuce (L. sativa), of which only $15 \%$ are crisphead, the rest being a conglomeration of romaine, leaf, latin, butterhead, and stalk types (Jansen et al., 2006). A large collection of lettuce cultivars, PIs, breeding lines, and genetic stocks are preserved at 5 locations in the U.S. (Anonymous, 2004). These resources offer valuable germplasm for improvement of all types of lettuce. Use of interspecific crosses of $L$. sativa with other related lettuce species from throughout the world has been integral in development of the elite lettuce varieties of today. Novel sources of genetic diversity will be required for lettuce breeders to effectively meet the future needs of cultivar improvement for disease and insect resistance, nutritional value, horticultural quality, and environmental adaptability. The U.S. consumer continues to develop new prefer- ences for lettuce types other than crisphead and lettuce breeders must concomitantly change their product models to adapt.

\section{Literature Cited}

Anonymous. 1956. New vegetable varieties list III. Proc. Amer. Soc. Hort. Sci. 67:587-609.

Anonymous. 1958. New vegetable varieties list V. Proc. Amer. Soc. Hort. Sci. 71:591-600.

Anonymous. 1960. New vegetable varieties list VI. Proc. Amer. Soc. Hort. Sci. 75:842-848.

Anonymous. 1965. New vegetable varieties list $\mathrm{X}$ and XI. Proc. Amer. Soc. Hort. Sci. 86: 824-841.

Anonymous. 2004. Leafy vegetable crops germplasm committee report. 12 Nov. 2006. www.ars-grin. gov/npgs/cgc_reports/LVCGCCropRpt104.pdf.

Anonymous. 2006. National Agricultural Statistics Service. U.S. Dept. of Agr. Agricultural statistics database. 02 Jan. 2007. http://www.nass. usda.gov/.

Bohn, G.W. and T.W. Whitaker. 1951. Recently introduced varieties of head lettuce and methods used in their development. U.S. Dept. of Agr. Circ. 881.

Center for Genetic Resources. 2006. Plant research international. 02 Jan. 2007. http://www.cgn. wageningen-ur.nl/pgr/.

Compositdb. 2006. Lettuce cultivar database. 02 Jan. 2007. http://compositdb.ucdavis.edu/ database/lettcv2/display/.

Cook, A. 2002. Back to the basics of lettuce. Washington Post, 21 Feb. 2002.

Dunne, M. 2005. Head of the class Iceberg is the plainest lettuce of all-And the most popular Sacramento Bee Jan. 26, 2005, McClatchy Newspapers, Inc.

Hu, J., O.E. Ochoa, M.J. Truco, and B.A. Vick. 2005. Application of the TRAP technique to lettuce (Lactuca Sativa L.) genotyping. Euphytica 144:225-235

Jagger, I.C., T.W. Whitaker, J.J. Uselman, and W.M. Owen. 1941. The Imperial strains of lettuce. U.S. Dept. of Agr. Circ. 596.

Janis, M.D. and J.P. Kesan. 2001. Designing an optimal intellectual property system for plants: A U.S. Supreme Court debate. Nat. Biotechnol. 19:981-983.

Jansen, J., H. Verbakel, J. Peleman, and Th.J.L. van Hintum. 2006. A note on the measurement of genetic diversity within genebank accessions of lettuce (Lactuca sativa L.) using AFLP markers. Theor. Appl. Genet. 112:554-561.
Johnston, C.S., C.A. Taylor, and J.S. Hampl. 2000. More Americans are eating ' 5 a day' but intakes of dark green and cruciferous vegetables remain low. J. Nutr. 130:3063-3067.

Lebeda, A., I. Dolezalova, V. Ferakova, and D. Astley. 2004. Geographical distribution of wild Lactuca species (Asteraceae, Lactuceae). Bot. Rev. 70:328-356.

Lower, R.L. 1973. New vegetable varieties list XIX. HortScience 8:465-470.

Mikel, M.A. 2006. Availability and analysis of proprietary dent corn inbred lines with expired U.S. plant variety protection. Crop Sci. 46: 2555-2560.

Mikel, M.A. and J.W. Dudley. 2006. Evolution of North American dent corn from public to proprietary germplasm. Crop Sci. 46:1193-1205.

Ryder, E.J. 1979a. 'Salinas' lettuce. HortScience 14:283-284.

Ryder, E.J. 1979b. 'Vanguard 75' lettuce. HortScience 14:284-286

Ryder, E.J. 1981. 'Sea Green' lettuce. HortScience 16:571-572.

Ryder, E.J. 1986a. Lettuce Breeding, p. 433-474. In: M.J. Bassett (ed.). Breeding vegetable crops. AVI Publishing Co., Westport, Conn.

Ryder, E.J. 1986b. 'Winterset' lettuce. HortScience 21:1464-1465.

Ryder, E.J. 1991. 'Salinas 88' lettuce. HortScience 26:439-440.

Ryder, E.J. and B.J. Robinson. 1991. 'Pacific' lettuces. HortScience 26:437-438.

Thompson, R.C. 1951. Lettuce varieties and culture. U.S. Dept. of Agr. Farmers Bul. 1953.

Thompson, R.C. and E.J. Ryder. 1961. Descriptions and pedigrees of nine varieties of lettuce. U.S. Dept. of Agr. Tech. Bulletin No. 1244.

U.S. Dept. of Agriculture (USDA), Agricultural Research Service. 2005. USDA nutrient database for standard reference. Release 18 . Nutrient Data Laboratory Homepage. 02 Jan. 2006. http://www.nal.usda.gov/fnic/foodcomp.

Waycott, W. and E.J. Ryder. 1994. 'Ice Cube', 'Blush', and 'Mini-Green' miniature crisphead lettuce cultivars. HortScience 29:333-334.

Wehner, T.C. 1999. Vegetable cultivar descriptions for North America List 24. HortScience 34:763-806.

Whitaker, T.W. 1974. Lettuce: Evolution of a weedy Cinderella. HortScience 9:512-514.

Whitaker, T.W. and R. Provvidenti. 1983. Collecting lettuce germplasm in Turkey and Greece. HortScience 18:285-288. 